\title{
The Tragedy of the Commonplace: Clichés in the Age of Copyright
}

\author{
Jakob Norberg
}

Garrett Hardin's 1968 article "The Tragedy of the Commons" seeks to explain how collectives end up spoiling the very resources on which they depend. The story begins with an open pasture, the commons. Each herdsman in the area who can keep cattle on this open pasture will do so, to feed them and thereby sustain his own existence. And each herdsman will let as many of his animals graze as he possibly can, since it comes at no cost. Yet the pasture cannot possibly nourish such a large number of animals without interruption and the quality of the shared lands will start to deteriorate. The imagined pasture will be spoiled.

A pasture open to all will be ruined by all; this is Hardin's conclusion. The question is how to prevent the destruction of a shared asset, or avert the "tragedy," defined as the "remorseless working of things" (Hardin 1968: 1244). How do we preserve the pasture from overgrazing? Or how, to introduce other examples, do we counteract overfishing in the deep seas or pollution of the air? The problem of protecting the ocean and the atmosphere are particularly challenging, because the air and waters are perpetually used by all and "cannot readily be fenced" (Hardin 1968: 1245). It is possible to close off and divide up an open pasture among property owners who will prudently manage their plots, but some commons elude the imposition of boundaries, making the tragedy seem inescapable.

Yet there are also examples of commons invulnerable to overexploitation and hence immune to tragedy. They are not to be found in the domain of natural resources. Something not quite as tangible, such as knowledge, would be one example. Once an insight has been formulated and can be transferred from one mind to another, it can be difficult to exclude people from appropriating it. But one person's acquaintance with a particular insight does not necessarily reduce other people's opportunity to benefit from it (Hess and Ohlin 2011). Unlike shared grazing lands, a piece of knowledge or an idea in most cases constitutes a "nonsubtractive resource" (Hess and Ohlin 2011: 5). My knowledge of Eurasian geography, for instance, does not subtract from yours.

Language represents yet another example of a nonsubtractive commons: it is a shared resource, it belongs to us all, and words are never consumed, no matter how often we use them. Regardless of how greedy or reckless we might be, no tragedy threatens our resources of expression and communication. But this is not always so. There are cases in which language, or rather particular formulations, become subject to a dynamic much like the tragedy of the commons. Such a dynamic unfolds under the name of the cliché, our term for expressions that have lost their value through a process of repetition and overexposure. Formulations that we use constantly, and consequently encounter constantly, at some point do lose their attractive qualities; they no longer seem witty, clever or illuminating to us (Amossy 1982).

Our shared stock of expressions does in certain cases represent a commons vulnerable to spoiling through overexploitation by a mass of individual speakers, and no area of language can be easily fenced off. As we shall see, definitions and descriptions of the cliché even rely on a persistent imagery of exhaustion, wear and tear, and gradual waste, an imagery of erosive overuse. There seems to be something we can legitimately call the tragedy of the commonplace through which formulations lose their value. As users of search engines, we are perhaps more attuned to how the value of words, their actual monetary value, increases with their ubiquity. The more people search for a word online, the higher the price for an advertisement connected to this word; popularity equals worth (Kaplan 2014). But while the topic of the decaying value of supposedly overused words and expressions might seem curious 
one, it nevertheless merits our attention, because it exhibits how language constitutes a contested type of commons, a resource used by all and fought over by many. What strategies, I will also ask, are available to those who wish to protect shared verbal resources from overuse?

\section{The Problem of the Commons in the Realm of Aesthetics}

A cliché, a 1972 dictionary of literary terms states, is a word, phrase or expression that "has lost its originality and impact through constant and prolonged use" (Shaw 1972: 79). The definition seems uncontroversial. Contemporary editors can without any further elaboration declare that clichés are simply "overused expressions": "Once these expressions were original but today they are stale and trite" (Jaderstrom and Miller 2005: 28). But many words and phrases appear constantly and yet no one speaks of their depletion. The critic Laurence Lerner points out that formulas such as "What is the time?, good evening, Afraid we must be going now, are commonplaces that do not wear out" and that metaphors such as the "legs of the table" can become dead metaphors without anyone expressing irritation (Lerner 1956: 250). These everyday phrases continue to do their jobs quietly and attract little attention; constant use does not necessarily entail overuse.

But some phrases, perhaps especially those that were once meant to be original and ingenious and possessed some special "freshness," appear to lose those features over time (Lerner 1956: 250). In an article entitled "Clichés," two veteran editors ask whether "people in your company use the following overused expressions? 24/7, branding, cautiously optimistic, cash cow, corporate culture, cutting edge" etc. (Jaderstrom and Miller 2005: 28). The sleek and clever phrases of corporate jargon are afflicted by the problem of overuse in a way that formulaic greetings are not, and we register the process by calling them clichés. Clichés are, one can say, high-profile expressions with relatively short and hence noticeable life cycles. The "velocity of adoption" also speed up the process of collective "abandonment" (Berger and le Mens 2009: 8146). Clichés are thus phrases that have become victims of "their own early success" (Hargraves 2014: 11). Consider the call to "think outside the box," a management consultant catchphrase that seems to have emerged in the 1970s (Kihn 2005). This is, or once was, a nifty way of calling for unorthodox thinking; it paints a simple but vivid picture of how to break out of a habitual frame. Now most of us cannot hear the exhortation without rolling our eyes; it is, according to an editor of the Oxford English Dictionary, about "as clichéd as it gets" (Kihn 2005).

The dynamic can be understood as a process quite like the tragedy of the commons. A certain phrase or expression is perceived to be smart, elegant, or evocative in some way. The expression attracts speakers who deploy it in the hope of achieving some effect. Perhaps they seek to mobilize and inspire a corporate audience, seem creative or knowing, or maybe they just want to appear commonsensical or make sure that what they say is comprehensible. But the increasing use leads to the phrase's perceived overexposure and, ultimately, its explicit classification as a cliché - over time, some people, perhaps most, begin to judge it as worn out, unoriginal, stale; "repeated exposure" leads to a "dramatic drop off" in perceived vivacity (Clune 2013: 3). The collective of speakers who relied on the phrase to profit from its qualities waste those very qualities by means of their repeated use, at least in the eyes of the more sensitive members of the linguistic community, especially alert to the "dulling" of old ideas and formulations (Davis 1997: 247).

Garrett Hardin himself speaks in his article on the "evils of the commons in matters of pleasure" (1968: 1248). It is clear enough that the tragedy of the commons applies to areas that are either unprotected against forms of subtraction, for instance grazing and fishing, or available for different kinds of waste disposal; people want to drive, factories want to produce, but the commons, the air we breathe, ends up dangerously polluted. But Hardin also provides examples of the tragedy of the commons in the realm of sensory pleasure. There is, for instance, no restriction on the "propagation of sound waves in the public medium" (Hardin 1968: 1248). Stores and other facilities play music to achieve some desired effect, say to sooth or stimulate shoppers, but the cumulative effect is that the public is at all times "assaulted with mindless music, without its consent" (Hardin 1968: 1248). In this case, the regrettable end result of the development is not spoiled lands and hungry cattle, overfished oceans or toxic smog, but frayed nerves. It is exhausting to move through cacophony, a polluted aesthetic environment; there are minitragedies in the realm of mental life.

The tragedy of the commonplace likewise represents a kind of creeping attack on human sensibility. A phrase first seems to capture and express something about the world or it possesses some particular quality, but through 
overuse by a mass of speakers, by unfortunate ubiquity, it ceases to be engaging or illuminating and instead becomes annoying. The problem here is not overload as a result of an endless sensory assault, but perhaps a kind of low-level boredom and irritation. To paraphrase Hardin, clichés could be categorized as an evil of the commons in the realm of the aesthetic.

\section{The Tragedy of the Commonplace and the Failure of Regulation}

A cliché, Merriam-Webster states, is a "trite phrase or expression" and in the discussion of synonyms that follows, trite is said to apply to "a once effective phrase or idea spoiled from long familiarity" (Merriam-Webster 2009: 231 and 1340). That which is trite has been worn out. The Webster section on etymology further informs the reader that trite comes from the past principle of the Latin terere, which means to rub or wear away. A cliché defined as a trite expression is a formulation that has been worn out, used to heavily or used for too long, gradually wasted by iteration; the cliché is understood through images of erosion, as if it were an overgrazed shared plot of land. But how does one prevent such wear and tear, the slow degradation through use?

Hardin does address measures that would halt or prevent overgrazing. To avoid the tragedy, he writes, the commons simply have to be "abandoned" (Hardin 1968:1248). When it comes to gathering food for animals and people, abandoning the commons means enclosing farmland and restricting pastures, hunting and fishing areas. Such transfers of "inefficiently managed common lands" into the hands of single owners allow - that is the idea - for more careful preservation and greater investment, which in turn enhances agricultural production in a way that is beneficial to all (Boyle 2003: 35). Privatization of common lands supported and enforced by a state with means of coercion is the adequate response to the tragedy of the commons; the "world is best managed when divided among private owners" (Carol Rose 1986: 712).

Much of the discussion about Hardin's essay has questioned the supposed choice between tragedy and coercively enforced privatization. The economist Elinor Ostrom's work on the management of the commons constitutes the most influential intervention in this debate. Against Hardin's stark parable, Ostrom marshals a wealth of empirical accounts of successfully managed commons and demonstrates that groups can effectively sustain shared resources, provided they have developed functioning mechanisms for conflict resolution and are able to define geographical boundaries and social membership. Hardin comes to his austere conclusion and suggests only a narrow set of measures, Ostrom argues, because he subscribes to a set of questionable assumptions, for instance that individuals who benefit from the commons do not communicate with each other, that they only act in their self-interest, and are insensitive to customs and other collective practices (Hess and Ostrom 2011: 11). Hardin's pastoralist, Rob Nixon writes, appears as a strangely monadic figure "exhibiting no social ties and existing, with regard to land use, outside of any evident cultural constraints, taboos, customary decrees, or collectively negotiated compromises” (Nixon 2012: 595).

But the problem of triteness, worn-out phrases and expressions, may prove intractable, for the simple reason that language cannot so easily be fenced off like fields and meadows and that other sanctions may remain ineffective. Does language by its nature resist processes of privatization and government coercion? One could think of analogous processes to privatization and coercion: government restrictions on use could correspond to censorship, privatization to authorship and copyright.

Censorship involves authorities of some kind, say a state or a church, examining and forbidding utterances that are politically or socially nonconformist (Darnton 2014). Publishing houses are closed down, newspaper offices vacated, books banned, passages edited out of individual texts, and authors persecuted. The history of such repressive control of public communication is long and far from concluded, but censorship is typically imposed to forestall rebellion, or at least the expression and dissemination of morally objectionable thoughts; it is not put in place to protect neat phrases from possible future overuse. Censorship of clichés would be overkill.

The idea that an author's rights over his or her text represents a privatization of language deserves more scrutiny. As is well known, ownership over a particular text has not always been a simple "fact emerging from the text's composition" (Fitzpatrick 2011: 58); copyright is a fairly recent legal institution. It was only over the course of the eighteenth century that texts emerged as a kind of property belonging to their authors (rather than the printer, the book seller and other parties involved in book production and distribution), a process that can be traced through a sequence of legal battles and public debates (Mark Rose 1993; Bosse 1981). 
Accompanying and underpinning this gradual and contentious reform in the domain of legislation was a set of modern assumptions about authorship, namely that the individual author who writes a text expresses his or her original ideas in a specific form and that particular utterances have their source in particular, creative minds. Yet in the legal context, the image of the creative author was intimately connected to a theory of incentives: writers protected by copyright will be well-compensated for their efforts and then also be properly inspired and incentivized to continue their efforts (Spoo 2013: 8-9). A society of ownership is more productive - that is one justification for intellectual property, but also for the transfer of common, mismanaged lands into private control of dedicated individuals.

The establishment of author's rights nevertheless does not amount to a neat privatization of areas of language, which would forestall erosive overuse of clever phrases. Eighteenth-century champions of authors' rights, the literary scholar Mark Rose points out, tended to argue that literary property should be seen as analogous to real estate, all in order to stabilize rhetorically the conception of the author as indisputable owner of a work (Mark Rose 1993: 7-8). Yet nobody can completely prevent the further (erosive) use of specific combinations of words into phrases that then partly make up "owned" texts; the phrases still function as a resource accessible to all and are hence characterized by "ephemeral ownability” (Apter 2009: 113). A commercial entertainment company with copyrighted figures such as Disney can "practice good husbandry of its characters" to avoid cultural overexposure, but it is quite a bit harder to prevent the further circulation of well-composed sentences or witty expressions (Landes and Posner 2001: 13). And yet attempts to claim legal ownership over words and word combinations do take place: the artist Taylor Swift has successfully managed to trademark phrases such as "this sick beat," which means that they cannot be used by others for commercial purposes, say as mottos on T-shirts, guitar straps or greeting cards, without a license (Grow 2015).

In the realm of literature, the question of literary ownership is typically debated under the rubric of plagiarism, our term for alleged attempts to steal or pass off the words of another person as one's own words. If the actual source of even a single formulation is not appropriately mentioned, if the reference is suppressed, we have a case of plagiarism, which most writers, teachers, and scholars consider "the capital intellectual crime" (Posner 2007: 107). But proper citation practices do not prevent the overuse of particular phrases; it serves to channel the reader's attention in the right direction, namely to the author who once constructed it.

Rules against plagiarism and the conventions that allow for quotation hence provide no fullproof defense against triteness and are not designed to avert the particular tragedy of expressions becoming spoiled from constant use. Formulations can suffer degradation even though everyone knows who once assembled them and no plagiarism takes place. "What does not kill me makes me stronger" is a quotation that everyone knows stems from Friedrich Nietzsche, but the phrase itself has become nonetheless become a victim of its overexposure. Laws against plagiarism and perhaps even trademarked phrases might not perfectly prevent the tragedy of the commonplace.

\section{Strategies Against the Tragedy of the Commonplace}

Neither government intervention in the form of censorship, nor privatization in the form of authorship, can or were meant to prevent expressions from being worn out by overuse. But there may still be ways to regulate and protect the shared resource of language. The linguistic community can at least suggest restrictions on its own use of phrases and enforce those restrictions by means of softer, reputational pressures. Which strategies are available?

Irritated by clichés, vigilant readers and listeners sometimes put together lists of clichés, partly to provide an amusing look at popular linguistic tics but not infrequently to enjoin speakers to stay away from exhausted phrases. There are lists of political clichés, lists of sports clichés, lists of business clichés, and so on. Here is the announcement of one recent list, which appeared in the Washington Post:

Identifying clichés has become a favorite Washington parlor game. But might it not also open a rare window onto the struggles of writers and editors trying to think outside the box? Over the past few years, some colleagues at the Washington Post and I have played our own parlor game, assembling a list of verbal crutches, stock phrases, filler words, clichés and perpetually misused expressions that we should avoid in The Post's Sunday Outlook section-or at least think hard about before using. (Lozada 2014)

The list that follows, and that includes the expression "a favorite Washington parlor game," "think outside the box," and "offers a rare window," is entitled "Things We Do Not Say" (Lozada 2014). It represents an index of 
prohibited expressions, without the support of an official authority but issued from the ranks of professional writers. The article of course is meant to be an entertaining look at verbal habits, but it is still governed by a serious notion of a good, non-repetitive and non-redundant style of journalistic writing.

A common response to clichés, then, is to record them, gather them and put them in the unenforceable quarantine of a list of expressions with some label like "12 Clichés All Writers Should Avoid" (Klems 2012) or even "681 Clichés to Avoid in Your Creative Writing” (Luke 2014). Some alert readers, or some especially cranky readers, dream of tougher measures against trite expressions, but unless they can issue an actual editorial rule for a newspaper, radio station or some other media outlet,[1] those who collect clichés must remain content with offering recommendations, with the hope that others will accept guidance in matters of style. The genre of the list is not an instrument of censorship, but an attempt to enable collective self-monitoring in the realm language.

It is doubtful whether expressions left alone for a while will one day seem fresh or interesting again; "think outside the box" is probably terminally exhausted and the linguistic community as a whole should move on. The purpose of the fight is instead to reduce irritation. In this struggle to limit annoyance, two kinds of threats are common, or two ways of trying to cordon off spoiled domains of language. The first threat is apparently benign, delivered as pedagogical advice from instructors to students, editors to writers, or expert writers to less confident ones: you ought to avoid clichés because trite expressions make your writing less interesting, less engaging, and you will lose your audience. Compilations of clichés serve as checklists or devices of self-editing for writers interested in effective communication. Regulation of language appears in the guise of rhetorical mentoring.

The second kind of threat is more aggressive. The main premise of this line of attack is that those who rely on clichés are failing as writers, that they are sloppy, lazy, or obtuse. Texts full of clichés are not the unfortunate products of educable novices or overly hasty writers; they are revealing records of mediocrity and mindlessness. Clichés, the literary critic Frank Kermode writes, "are infallible symptoms of used thinking” (2001: 27). By casting scorn on clichés, or by announcing the cliché's symptomatic significance, critics no longer seek to nudge people into more careful composition but impose reputational penalties on already committed crimes by means of public ridicule; they use shame to enforce cooperation (Jacquet 2011). With the institution of literary criticism in place in the public sphere, authors who publish their works face the prospect of being attacked, of being shamed, a deterrent to socially unwanted behavior, in this case their further, annoying use of already overused verbal resources.

In a collection of essays entitled "The War on Cliché," the author Martin Amis engages in the game of mocking authors for their reliance on cliché, and praising authors who parody "ready-made formulations" and "fossilized metaphors" (2001: 444). Kermode sums up how Amis goes about it:

Over the years, Amis has done a lot of virtuous wincing over clichés. John Fowles is a prominent target: 'He managed a wan smile'; 'God, you're so naïve.' No expensive talk about Descartes, Marivaux, Lempriere and Aristophanes can procure a pardon for that sort of thing. Other reviewers may commend Thomas Harris for committing 'not a single ugly or dead sentence' but Amis finds enough of them to label Harris a 'serial murderer of the English language' and Hannibal 'a necropolis of prose.' (Kermode 2001: 27)

The language of punishment is telling: the writer who uses clichés perpetrates a crime for which his other virtues are no excuse; he is the target of an attack, and so on. We are no longer in the realm of instruction and advice, but in that of harsh public judgments.

Attempts to prevent overuse in language thus appear both as helpful suggestions for aspiring writers and as ridicule directed at hacks. The genres that correspond to the two approaches are the prescriptive writing style guide, on the one hand, and the damning review, on the other. One could say that the self-appointed regulators of language assume positions of monitoring at the beginning and the end of the writing process. They first try to caution people from using overused expressions, and then shame those who lacked the discipline or wit to eliminate them. In both cases, however, the cliché, a problem that arises because language is a common resource, cannot be by fought by outright censorship or protection of authors' rights. Instead, the critics of the cliché have to rely on everyone's willingness to avoid wasted areas of language for the sake of ensuring their own communicative success and maintaining their status. Here one can point out that the concept of the cliché itself is not neutrally descriptive but negatively charged and pragmatically applied precisely as a device to expose an otherwise unpunished overexploitation. There is not a "war on cliché" waged by highbrow critics and authors on some indisputably present target; the term "cliché" itself is the cultural war, a device by which to name perceived overuse and a weapon by which to fight it. 


\section{Authors' Rights and the Cliché as Crime}

In the fourteenth and fifteenth century, Hackney was a village outside of London surrounded by grasslands and known for the horses bred and pastured there. Riding horses became so closely associated with the place that the word, hackney, became a standard term for horses. And since these riding horses were often hired out, the word also came to refer to horses or carriages, and later cars, let out for common hire. From the seventeenth century on, a "hack" also came to designate person who works for mercenary reasons - a writer, journalist or propagandist for hire. But yet another meaning emerged; horses for hire, or horses ridden by any number of people rather than in the possession of a single person, were typically overworked. This perception then influenced the meaning of the word hackneyed, which began to refer figuratively to "something that was overused to the point of drudgery" (Quinion 2002).

Hackneyed, the dictionary tells us, belongs to the same crowd of words as trite and threadbare; hackneyed phrases or slogans are lacking in freshness and originality, having lost their appeal or interest through overuse. Once again, images that surround the concept of the cliché recall processes of gradual spoiling. Language may be a nondepletable resource, but as the metaphors of perpetual use and exhaustion imply, the interest or effectiveness of particular word combinations, as opposed to the words themselves, can in fact be wasted, and to prevent it, speakers and writers are continually cautioned and shamed by language's self-appointed guardians.

To refer to the author Martin Amis once again: “'He managed a wan smile'; 'God, you're so naïve.' No expensive talk [...] can procure a pardon for that sort of thing” (Kermode 2001: 27). The use of clichés apparently constitutes a near-criminal offense, a crime in the realm of style perhaps, or some wrongdoing in the realm of pleasure. What exactly does the criminal act consist in? Of course, those who now urge us to "think outside the box" do nothing but annoy us. The phrase has become offensively under-stimulating and its continued circulation pollutes the shared environment; every cliché is a kind of waste product and it is this littering of our public discursive spaces that is criminal.

But the forensic investigation has not been concluded. The cliché is not only an irritation to others, but a revelation: the person who inserts overused phrases in written and spoken language exposes him- or herself as uncreative, as someone who cannot or does not want to assemble a novel formulation but relies on the already said. This is a speaker who apparently wants to benefit from the shared resource, the stock of formulations to which all speakers have access but does not seem overly concerned with making a contribution to that stock. In a sense, the speaker who deploys an already composed and available phrase reveals a desire to obtain some benefit without much effort. When a critic censures a writer for using outworn phrases and labels his or her style clichéd, we may be witnessing an attempt to point to the pollution of the aesthetic environment, but also to expose parasitical behavior.

The analysis of any type of commons, Charlotte Hess and Elinor Ostrom writes, "must involve the rules, decisions and behaviors people make in groups in relation to their shared resource" (2011: 10). The basic problem that these group then have to address is the problem of free riding, "where one reaps the benefits from the commons without contributing to its maintenance" (Hess and Ostrom 2011: 10). Language, too, is a shared resource, and the cliché designates the crime of using the shared means to achieve some goal without much independent effort, whatever that goal may be (say producing a text of 3,000 words in one evening). The cliché constitutes a problem of free riding, of using but not contributing to the commons, and the lack of creativity it reveals simultaneously bespeaks a weak commitment to the collective's resources, to the task of protecting and refreshing them. This reasoning partly sheds light, I think, on the half-serious righteousness of a "war on cliché" and the talk of punishment and pardon. The continued use of already overused expressions represents both the offense of producing an annoyance and the offense of free riding, or a failure to keep waste out of our aesthetic environment as well as a failure to regenerate that environment.

The demand that one should try to introduce something new to the language on which one relies is particularly pronounced in the age of author's rights. As mentioned, author's rights were meant to allow authors to profit from their labor. After they invest their time and effort in writing a book, authors should be able to gain recognition from its distribution and consumption by the public; the use of language is their livelihood in a market. This conception of author's rights, established at the end of the eighteenth century, is, as most students of literature know, tied to Romantic notions of originality and individuality. Authors struggling to make ends meet after the decline of patronage, early eighteenth-century authors began to claim ownership over texts by invoking their creative spirit; genius and copyright belonged together from the very beginning (Woodmansee 1984). When we speak of an author 
today, we mean "an individual who is the sole creator of unique 'works' the originality of which warrants their protection under laws of intellectual property known as 'copyright' or 'author's rights”' (Woodmannsee 1992: 279). Viewed legally and economically, literary originality allows us to link a particular person to a particular text in the market for books.

This modern conception of authorship and its economy helps explain the vitriol against the cliché, especially if spotted in texts of any kind for which someone can expect some kind of reward, whether it is monetary or reputational. When an author in the sense of a sole creator relies on previously created and indeed overused phrases, he or she betrays the core premise of author's rights, namely the idea that the claims of authorship and literary ownership rest on original expression, which in turn is a manifestation of individual personality. Whether consciously or not, the writer who relies on clichés is offering us shared resources as if they were private or tries to secure compensation for an investment they have not really made. In a sense, the author's name should simply not be attached to the work, for it does not fully belong to her; the cliché attenuates the link between text and person that the signature asserts.

The cliché or the overused expression appears as an author's failure to meet the interest in stimulating variety, but also his or her failure to honor the legally and economically significant imperative of originality. The two are distinct. Quintillian, the ancient teacher of rhetoric, could complain about orators who relied too heavily on already established formulations with a proven record of success; a sophisticated public would, he claimed, reject wellknown loci communes as they would reject, with disgust, a plate of cold leftovers (Coenen 2009: 401). Even in ancient times, it seems, publics demanded novelty, although the pace of the cultural metabolism was likely much slower then; our current media climate, governed by the imperatives of fast capitalism, has quickened the production of waste - cultural consumption is accelerating (Agger 2004).

The gradual establishment and consolidation of author's rights over their works in the late eighteenth and early nineteenth century added to the aesthetic demand for variety and newness the modern demand for recognizable individuality. In a literary market, the name of the author functions like the name of a manufacturer or company - it establishes the "brand identity" of the work, all in order to assure customers of quality (Posner 2007: 69). It is in this context that the reliance on allegedly exhausted, clearly unoriginal phrases becomes a problem. The critique of the cliché, mobilized by figures such as Martin Amis, works as a cultural alarm system for the protection of authorship as an institution that links individual, expressive writing to rewards in a cultural market.

\section{The Cliché and the Propertization of Literature}

In this context, I offer the following hypothesis: under the modern regime of literary property rights, the exasperation with the cliché stands in some proportion to the benefit that someone expects to derive from an utterance. Athletes compelled to give interviews frequently say just what everyone else is always saying ("We're taking it one game at a time"), but they are routinely forgiven, for they earn their money by winning on the field rather than composing texts.

Literary authors who slip in worn-out expressions in books are, by contrast, betraying a requirement inherent to their professional activity in the market and can expect a terrible review; now the annoyance is mixed with righteousness - they are not fulfilling the normative expectations of expressiveness and individuality that ground their ownership and justify any received rewards.

Journalists represent a middle case in this context. On the one hand, they do earn their money by writing and people complain about journalistic writing cluttered with clichés; in journalistic texts, lawns are frequently "manicured," track records "proven," battles "hard-fought" and so on - journalism is the home of the cliché (Hargraves 2014: 13). On the other hand, journalists writing reports for newspapers or news sites are not rewarded for their originality but are supposed to produce texts with an easily comprehensible, collective style. Hence readers frequently complain about clichés in journalistic writing, but few individual journalists are singled out for shaming; articles are not reviewed, and individual journalists not shamed.

The individualization of authorship and the privatization of literary styles in the era of copyright makes the reliance on commonplace look suspect. In fact, the propertization of literature, the conversion of texts into owned things, is not necessarily the remedy for the tragedy of the commons in the realm of language, but could be its origin, since the demands of original authorship are precisely what has intensified the angry critique of the reliance on 
frequently used phrases. It is only in a post-Romantic world in which authors appear as the rightful owners of their original creations that the use of already established expressions and word combinations becomes a nearly criminal verbal act.

But even if author's rights on the expanding market for books create the conditions for an intensified critique of the overused phrase, the complaint about clichés does not necessarily follow an obvious commercial logic. The critique is in fact often explicitly anti-commercial, and voiced by authors and critics who wish to maintain the autonomy of the cultural sphere vis-à-vis crude economic interests (Bourdieu 1993). Given variances in the sensitivity to perceived linguistic overuse between sophisticated expert readers and large groups of more occasional consumers, it is perfectly possible for an author to produce entirely unoriginal books, filled with supposedly worn-out phrases, and nonetheless make huge profits. The expanded book market in the age of mass literacy does not necessarily punish an obvious lack of stylistic originality through tepid sales; quite the contrary. On the contrary, authors who write in a simple and easily-digested style, replete with familiar expressions, might very well gain a greater readership, to the horror of professionalized critics who respond by delineating and policing a "high literary zone" (Radway 1997: 140-41).

In a public sphere in which derivative writing meets with commercial success, the critique of the cliché can function as an instrument of harsh invalidation in the face of a book's undeniable market strength; no critic or reader has simply to accept an author's popularity but can recast it as more or less based on artistic failure and refuse endorsement. Authors and critics of the nineteenth century engineered the uncoupling of commercial success, on the one hand, and the conferral of cultural prestige through peer recommendation, on the other (Leypoldt 2014). It is precisely the critic intent on monitoring the border between genuine art and commercial pandering who needs the critique of the overused phrase, for he or she will want to point to unearned appreciation and hollow claims to originality - by exposing the hackneyed phrase in the bestseller. The critique of the supposedly overused commonplaces, which tend to cluster around commercially viable literature, functions as a critique of the perennially unfair distribution of (monetary) rewards.

\section{Conclusion: Owning Words, Unownable Language}

It is now time to summarize the points of the argument:

1. Language constitutes a nonsubtractive social resource and yet the appeal of particular expressions can be wasted; there is something one could call the tragedy of the commonplace. The gradual erosion of the qualities of shared expressions is reflected in the persistent imagery of waste that surrounds the common phrases, the clichés: word combinations are typically characterized as "worn out," "trite," "dull," "hackneyed" etc.

2. The steady depletion of shared verbal resources cannot be contained by means analogous to coercion (censorship) or privatization (copyright). The social nature of language does not allow such measures. In this situation, critics seek to halt the ongoing erosion of phrase quality and reduce the irritating effects of linguistic detritus by means of composition advice and critical reviews that single out the rhetorical ineffectiveness or symptomatic value of the cliché. Those who rely on clichés are judged to be rhetorically inept, or lazy and talentless. The self-appointed regulators of language use and guardians of cultural prestige must rely on strategies of mentoring and shaming.

3. The critique of the cliché, the spoiled verbal commonplace, emerges, or at least intensifies, under the copyright regime of the modern cultural market, in which authors are supposed to be rewarded for their individual creative literary products. The cliché is attacked as a near-scandalous dependence on the efforts of others, as literary free riding, in texts for which the authors are nonetheless compensated in some way. In this way, the attack on the cliché is often most vehemently directed at authors who are deemed stylistically uncreative but nonetheless achieve commercial success.

But there is something problematic about the whole process summarized above, specifically the conception of language as the field of individual creation regrettably vulnerable to collective use. Under modern copyright rules designed to institutionalize the link between identifiable individual creation and reputational or monetary rewards, actors in culture place a high value on the originality of literary products, while knowing that originality or at least novelty cannot quite be protected; the statements of authors can always be cited and copied, their expressions recycled and seemingly drained of value. The apparent overexploitation of shared verbal matter, the tragedy of the commonplace, is a dynamic that plays out constantly in the literary field; its members valorize originality and novelty 
and yet have no obvious way of sheltering the manifestations of creativity from depletion and decay - because language remains stubbornly shareable and un-ownable. The cliché will not go away.

Critics attempt to penalize the continued use of phrases by attaching negative labels to speakers, by rolling their eyes at those who resort to clichés; the unceasing hunt for the new and original is accompanied by irritation at the dull and exhausted. And yet the cliché is a symptom that cannot be fully eliminated (in capitalism), despite constant attacks on their badness, because clichés are generated when a market logic demands the enforcement of ownership over forever un-ownable words. In this way, the cliché actually serves as a reminder of the radically social character of language.

The cliché will disappear not when critics have managed to train or scare all speakers into non-repetition and hyper-individualized speech, but when we have moved beyond the model of the author as "solitary genius or diligent entrepreneur" and instead begin to see writers as "social actor[s]" who seek to alter the world by means of the reverberations of their words (Agger 2001: 185). The cliché is a problem in a literary system in which individual authors are supposed to profit from their words, because those who repeat formulations must be condemned as free riders. But the cliché might not be a problem, and might perhaps not even become visible, in a transformed social context in which authors strive above all to be agents who "effect social change" in the world, for then those who speak as the author does are not epigones and parasites but allies in a mobilized public discourse (Agger 2001: 185). Within a movement with a shared discourse, common causes prevent the tragedy of the commonplace.

\section{Endnotes}

1. Randy Michaels, a broadcasting executive, apparently did put together a list of unacceptable expressions that the radio staff was supposed to follow. "The man at the top of the troubled media empire [Tribune Co.] took time out of his real job this week to issue a list of words and phrases -119 of them, to be exact - that must never, ever be uttered by anchors or reporters on WGN-AM (720), the news/talk radio station located five floors below his office in Tribune Tower." See Robert Feder, "Memo puts WGN staffers at a loss for words," http:// www.wbez.org/feder/2010/03/memo-puts-wgn-newsstaffers-at-a-loss-for-words/17374.

\section{References}

Agger, Ben. 2001. "Are Authors Authored? Cultural Politics and Literary Agency in the Era of the Internet. Democracy \& Nature. 7.1: 183-203.

2004. Speeding up Fast Capitalism: Cultures, Jobs, Families, Schools, Bodies. London: Routledge.

Amis, Martin. 2001. The War Against Cliché: Essays and Reviews 1971-2000. New York: Vintage.

Amossy, Ruth. 1982. "The Cliché in the Reading Process." Translated by Terese Lyons. SubStance. 11.2: 34-45.
Apter, Emily. 2008. "What Is Yours, Ours, and Mine: Authorial Ownership and the Creative Commons." October. 126: 91-114.

Berger, Jonah, and Gaël le Mens. 2009. "How Adoption Speed Affects the Abandonment of Cultural Tastes." Proceedings of the National Academy of Sciences of the United States of America. 106.20: 8146-8150.

Bosse, Heinrich. 1981. Autorschaft als Werkherrschaft: Über die Entstehung des Urheberrechts aus dem Geist der Goethezeit. Paderborn: Schönigh. 
Bourdieu, Pierre. 1993. The Field of Cultural Production: Essays on Art and Literature. Translated by Randal Johnson. New York: Columbia University Press.

Boyle, James. 2003. "The Second Enclosure Movement and the Construction of the Public Domain." Law and Contemporary Problems. 66.1: 33-74.

Clune, Michael. 2013. Writing Against Time. Palo Alto: Stanford University Press.

Coenen, H. G. 2009. "Locus communis.". Pp. 398-411 in Historisches Wörterbuch der Rhetorik, vol. 5, edited by Gert Ueding. Darmstadt: Wissenschaftliche Buchgesellschaft.

Darnton, Robert. 2014. Censors at Work: How States Shaped Literature. New York: Norton \& Co.

Davis, Murray. 1999. "Aphorisms and Clichés: The Generation and Dissipation of Conceptual Charisma." Annual Review of Sociology. 25: 245-69.

Feder, Robert. 2010. "Memo puts WGN staffers at a loss for words," http://www.wbez.org/feder/2010/03/memo-putswgn-news-staffers-at-a-loss-for-words/17374. Accessed June 23, 2018.

Fitzpatrick, Kathleen. 2011. Planned Obsolescence: Publishing Technology, and the Future of the Academy. New York: NYU Press.

Grow, Kory. 2015. “Taylor Swift Trademarks 'This Sick Beat' and other '1989' Phrases." rollingstone.com. https://www.rollingstone.com/music/news/taylor-swift-trademarks-this-sick-beatand-other-1989-phrases-20150128. Accessed June 23, 2018.

Hardin, Garrett. 1968. "The Tragedy of the Commons." Science. 162. 3859: 1243-48.

Hargraves, Orin. 2014. It's Been Said Before: A Guide to the Use and Abuse of Clichés. Oxford UK: Oxford University Press.

Hess, Charlotte, and Elinor Ostrom. 2011. "Introduction: An Overview of the Knowledge Commons.” Pp. 3-26 in Understanding Knowledge as a Commons: Theory and Practice, edited by Charlotte Hess and Elinor Ostrom. Cambridge MA: MIT Press.

Jacquet, Jennifer et al. 2011. "Shame and Honor Drive Cooperation.” Biology Letters. 7.6: 899-901.

Jaderstrom, Susan, and Joanne Miller. 2005. “Clichés.” OfficePRO. 65.7: 28 .

Kaplan, Frederic. 2014. "Linguistic Capitalism and Algorithmic Mediation," Representations. 127.1: 57-63.

Kermode, Frank. 2001. "Nutmegged." London Review of Books. 23.9: $27-28$.

Kihn, Martin. 2005. "Outside the Box: The Inside Story." Fast Company. http://www.fastcompany.com/53187/outside-box-inside-story. Accessed June 23, 2018.
Klems, Brian. 2012. "12 Clichés All Writers Should Avoid." http://www.writersdigest.com/online-editor/12-cliches-all-writers-should-avoid. Accessed June 23, 2018.

Landes, William, and Richard Posner. 2001. "Indefinitely Renewable Copyright." John M. Olin Law \& Economics Working Paper. 154: 1-48

Lerner, Laurence. 1956. "Cliché and Commonplace." Essays in Criticism. A Quarterly Journal of Literary Criticism. 6.3: 249-265.

Leypoldt, Günter. 2014. "Singularity and the Literary Market." New Literary History. 45.1: 71-88.

Lozada, Carlos. 2014. "200 Journalism Clichés - and Counting." Washington Post. http://www.washingtonpost.com/news/ opinions/wp/2014/02/27/the-outlook-list-of-things-we-donot-say/ Accessed June 23, 2018.

Luke, Pearl. 2014. "681 Clichés to Avoid in Your Creative Writing." http://www.be-a-better-writer.com/cliches.html. Accessed June 23, 2018.

Merriam-Webster's Collegiate Dictionary. 2009. 11th ed. Springfield, MA: Merriam-Webster.

Nixon, Rob. 2012. "Neoliberalism, Genre, and 'The Tragedy of the Commons." PMLA. 127.3: 593-599.

Posner, Richard. 2007. The Little Book of Plagiarism. New York: Pantheon.

Quinion, Michael. 2002. “Hackneyed.” World Wide Words. http://www.worldwidewords.org/qa/qa-hac1.htm. Accessed June 23, 2018

Radway, Janice. 1997. A Feeling for Books: The Book-of-theMonth Club, Literary Taste, and Middle-Class Desire. Chapel Hill: University of North Carolina Press.

Rose, Carol. 1986. "The Comedy of the Commons: Custom, Commerce, and Inherently Public Property." The University of Chicago Law Review. 53.3: 711-780.

Rose, Mark. 1993. Authors and Owners: The Invention of Copyright. Cambridge MA: Harvard University Press.

Shaw, Harry. 1972. Dictionary of Literary Terms. New York: McGraw-Hill.

Spoo, Robert. 2013. Without Copyrights: Piracy, Publishing, and the Public Domain. Oxford: Oxford University Press.

Woodmansee, Martha. 1984. "The Genius and the Copyright: Economic and Legal Conditions of the Emergence of the 'Author." Eighteenth-Century Studies. 17.4: 425-48.

1992. "On the Author Effect: Recovering Collectivity." Cardozo Arts \& Entertainment Law Journal. 10.2: 279-292. 